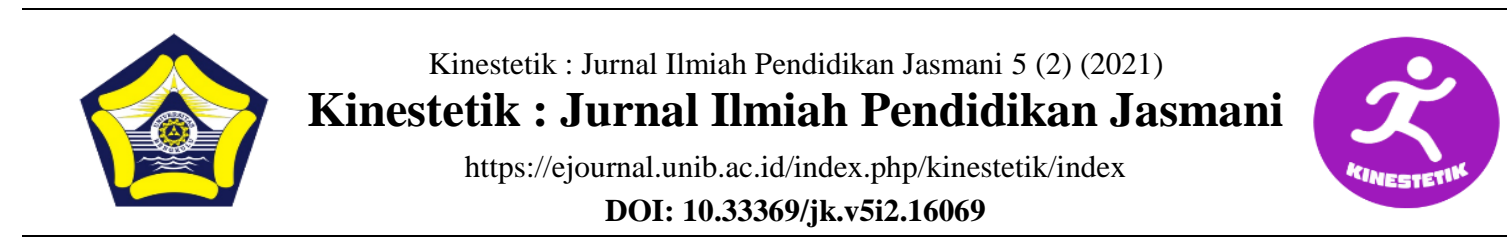

\title{
FLICK FLACK TRAINING TOOL FOR BEGINNER ATHLETES PERSANI MEDAN
}

\author{
Novita $^{1 *}$, Yasminne Nadia Khairunisa ${ }^{2}$ \\ ${ }^{12}$ Sports Coaching Education, Faculty of Sports Science, Universitas Negeri Medan, Sumatera \\ Utara, Indonesia
}

\section{Article Info}

Article History :

Received : May 2021

Revised : June 2021

Accepted : June 2021

Available online : June 2021

Keywords:

Tool, Flock Flack, Gymnastics

\begin{abstract}
Gymnastics is a body exercise on the floor or on a device designed to increase endurance, strength, flexibility, agility, coordination and self-control. One of them is floor exercise, this exercise also has various kinds of movements that are not easy to do, for example, the movement flick flack. Beginner athletes in PERSANI, Medan City have not mastered the movement properly flick flack due to limited tools and costs from PERSANI so that the coach has to innovate with existing tools. The population in this study were 9 Siahaanathletes Gymnastic Club, 5 Windy's Gymnastic Clubathletes, 2athletesathlete Star Kids Gymnastic Club and 1 QA Gymnastic Club in 2020. The Training tool was flick flack validated first by 9 experts, 3 experts in in sports, 3 experts in the field of equipment / media, 3 experts in the field of coaches, where the average percentage value of validity is $81.8 \%$, thus according to the experts they get the "Good / Feasible" category. The method used is the method of development research (Research and Development / $\mathrm{R} \& \mathrm{D})$. The results of the small group trial involved 14 athletes, 9 Siahaanathletes Gymnastic Club and 5athletes Wendy's Gymnastic Club that the development of the training tool flick flack in this study can be concluded that it meets the criteria to be continued in large group trials. The results of the large group trial involved 17 athletes, 9 Siahaan Gymnastic Clubathletes, 5 Windy's Gymnastic Club, 2 athletes. Star Kids Gymnastic Club and 1athlete QA Gymnastic Club concluded that they met the criteria to be used in helping training flick flack. From the results of the validation tool, test a small group and large group trial can be concluded that the tools exercise flick flack is needed in practice flick.
\end{abstract}




\begin{tabular}{|c|c|}
\hline 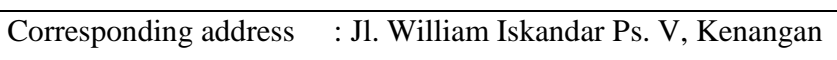 & ISSN 2685-6514 (Online) \\
\hline $\begin{array}{l}\text { Baru, Kec. Percut Sei Tuan, Kabupaten Deli Serdang, Sumatera } \\
\text { Utara }\end{array}$ & ISSN 2477-331X (Print) \\
\hline *Corresponding email $\quad$ : noviade@ unimed.ac.id & \\
\hline
\end{tabular}

\section{INTRODUCTION}

Gymnastics in the past had a negative impact on human growth, nowadays gymnastics is a sport as a health benefit and achievement (Exupério et al., 2019). Physical activities with many motion structures are seen from the general taxonomy of motion, gymnastics is represented by basic movements that build complete motion patterns from locomotor, non-locomotor and manipulative motion (Soni Kurniawan, Tono Suhihartono, yarmani, 2018). Federation Internationale de Gymnastique gymnastic competition numbers are Artistic Gymnastic, Rhythmic Gymnastic, Acrobatic Gymnastic, Aerobic Gymnastic, Trampolining, and General Gymnastic (Ratih Langenati, 2015). Gymnastics has types of gymnastics, including artistic, aerobic, dexterity and others (Soni Kurniawan, Tono Suhihartono, yarmani, 2018). Overall, there are four branches of gymnastics, namely men's artistic, women's artistic, rhythmic and aerobics sports. The four of them are directly under the guidance of PERSANI. PERSANI is the only gymnastics parent organization in Indonesia.

According to Muhajir, gymnastics is a body exercise on the floor or on a device designed to increase endurance, flexibility, agility, coordination and self-control (Hadjarati \& Haryanto, 2020). Very good with a percentage of $100 \%$ physical and 100\% mental (Firmansyah, 2017). In other words, gymnastics requires physical abilities and mental abilities, besides that it also requires endurance, strength, flexibility, agility, coordination and selfcontrol so it requires tools to practice. Furthermore, it is confirmed by the research of Paul Ford et al explaining that by using the development of appropriate exercise stimuli (development products) its relationship with the natural growth and maturation process by using the concept of a "home window" for acceleration and improving physical development (Paul Ford, Mark De Ste Croix , Rhodri Lloyd, Rob Meyers \& Jon Oliver, 2011).

In artistic gymnastics, competitions are adjusted according to the level, both regional, national and international competitions according to their respective competition numbers. One of them is floor exercises which are also called floor exercises. Gymnastics floor exercise floor also has a wide range of motion that is not fairly easy to do. It takes a long time for the athlete to make a perfect movement, for example, the bending of the hand back or what is commonly known as the flick flack. The flick flack is a movement that has similarities to the kayang movement, the difference is that it only begins with the initial attitude. This research begins with observations made by researchers for training flick flack carried out by athletes of the Siahaan Gymnastic and Windy's Gymnastic clubs in Persani, Medan City under the auspices of KONI.

To do the exercise flick flack, which is a flat mat. Not only that, the coach explained that all the athletes he trained were prospective athletes (beginners) aged 6-15 years. The trainer also explained that he had known that there was a tool for training, flick flack namely a large round mat, but PERSANI itself did not facilitate this tool for training flick flack, from the fact that in the field with limited training aids flick flack, researchers are interested in developing tools such as those available. on YouTube, then the researcher 
saw how the tool in question works through a video on YouTube, where in the video the mat rolls over according to the repulsion of the feet with the user lying on the back of the mat and the hands are stretched upward covering the ears with the body position like kayang then handstand which ends with the landing stands straight back. A coach solution so that novice athletes can change the kayang motion to a motion handstand to make it easier for athletes to get feeling the right when practicing the movement flick flack. It would be better if the aids were developed to make it easier for the trainer to practice flick flack according to the needs of the athlete and also the coach, so that the athlete is no longer assisted by the coach every time he exercises the movement flick flack. This is confirmed by the consideration of the factors of achievement development including clear coaching objectives, systematic training programs, appropriate training materials and methods, as well as evaluations measuring the success of the coaching process. In addition, looking at the characteristics of athletes, it is necessary to consider physically and psychologically, the ability to train, facilities and infrastructure, and the conditions of the coaching environment (Tommy, 2014).

A research that produces products in certain areas of expertise which also produces certain by-products and has the effectiveness of these products is referred to as development research (Saputro, 2017). In the end, researchers are interested in developing a training aid flick flack so that it is easier to adjust to the athlete's height, easy to move, with a round mat that can rotate $360^{\circ}$ to make it easier for athletes to use the tool for training flick flack. That way the tool is more efficient and the tool can be adjusted to the athlete's height.
It can be concluded that all artistic gymnastics athletes and trainers of PERSANI Medan need training aids flick flack in artistic gymnastics training to support the ability to movements flick flack athletes 'and be able to improve athletes' achievement in artistic gymnastics.

\section{METHODS}

Developing the beginning of the word development is defined as making it more perfect in other ways, processes or actions as an effort to achieve the desired goal of becoming perfect or a new product (Nurkadri, 2018). Furthermore, the guidelines for scientific writing at the State University of Malang in Nurkadri, solving actual problems by producing designs or products is a development (Nurkadri, 2018).This study uses the research method Research and development (R\&D)adopted from the Sugiyono development model which consists of developing existing products, testing the effectiveness of the product in order to achieve the desired goals, so that it can be used (Sugiono, 2016). Guidelines and instructions facilitate clear planning and design for conducting development research that produces a product (Sugiyono, 2012); (Palmizal et al., 2020). So this research carried out 4 (four) stages, namely: a) Potentials and Problems, b) Data Collection, c) Product Design, and d) Evaluation.

\section{Participants}

The research targets for the development of the training tool flick flack are the beginner athletes of PERSANI Medan who are all artistic gymnastics athletes in Medan. This study used trial people at PERSANI Medan at the GM Panggabean Prof. Gymnastics building. Drs. Jepta Hutabarat No.22 Medan Teladan. 


\section{Sampling Procedures}

The trial sample in this study was the phase I test and phase II test, where the first stage test was a small group of 2 clubs and a stage II test, a large group of 4 clubs aimed at athletes:

a. It was tested in phase I / small groups in this study. Researchers involved 14 athletes from Siahaan As subjects Gymnastic Club and Windy's Gymnastic Club.

a. b. Trial in phase II / large groups in this study the researchers will involve as many as 18-30 athletes who are still actively practicing at the Siahaan Gymnastic Club, Windy's Gymnastic Club, Star Kids Gymnastic Club and Sumber Juara Gymnastic Club.

\section{Materials and Apparatus}

For this development research, the data analysis technique used is the quantitative descriptive analysis technique with percentages. Sugiyono In Desni Yuniarti revealed that there were various types of data collection, namely observation, interviews, documentation, and combination (Yuniarni et al., 2019). Sudjana stated that this technique was used to obtain quantitative data analysis obtained from distributing questionnaires. This technique uses the following formula (Sujito, 2020):

$P=\frac{x}{x i} \times 100 \%$

Information:

$\mathrm{P}=$ Percentage of evaluation results of test subjects

$\mathrm{X}=$ Number of score answers by test subjects

$\mathrm{Xi}=$ Maximum number of answers in the aspect of assessment by test subjects $100 \%=$ constant
Table 1. Analysis of the percentage of validation results (Sujito, 2020)

\begin{tabular}{ccc}
\hline$\%$ & Information & Meaning \\
\hline $80 \%-100 \%$ & Valid & Used \\
\hline $60 \%-79 \%$ & Enough Valid & Used \\
\hline $50 \%-59 \%$ & Less Valid & Replaced \\
\hline$<50 \%$ & Invalid & Replaced \\
\hline
\end{tabular}

In this study, the product analysis after being made was validated on 9 experts consisting of 3 sports experts, 3 artistic gymnastics experts and 3 media experts, table 2 shows the following expertise:

Table 2. Expertise research products

\begin{tabular}{ll}
\hline Expertise in & \multicolumn{1}{c}{ names } \\
\hline sports & $\begin{array}{l}\text { Drs. Nono Hardinoto, M.Pd } \\
\text { Dr. Imran Akhmad, M.Pd } \\
\text { Drs. Tuhadi, M.Pd, }\end{array}$ \\
\hline Coach of & Safrizal, S.Sos \\
Artistic & Afrina Suryani Siahaan, SH \\
Gymnastics & Erwan G. Tua Siahaan \\
\hline Media & Ir. Batumahadi Srg, ST., MT, \\
& IPM \\
& Dr. Erma Yulia, MT \\
& Exaudi Tumanggor, S.Pd., Gr \\
\hline
\end{tabular}

The instrument used in this study used for needs analysis, questionnaires from the evaluation of expertise and the results of the opinions of people in the phase 1 trial and stage 2 trials. The instruments for identifying needs in this study were designed to collect data on the trainer's opinion on existing and moderate forms of exercise. They use flick flack. This instrument is also based on the concept of evaluating the form of exercise. The initial and main field test instruments are prepared through the concept of evaluation from athletes (Sugiono, 2016). The product of this research is a training tool flick flack modified. The results of this study can be used as a reference and input to the coach in varying the exercises using these tools, 
especially training flick flack for novice athletes. The following in table 3 shows the differences with the previous tools.

Table 3. Different tools developed.

\begin{tabular}{ll}
\hline Previous tools & Development Tools \\
\hline Price 5-10 million & Price 2 million \\
\hline $\begin{array}{l}\text { Tool size: } \\
\text { 1. } 25 \text { inch for } 121 \mathrm{~cm} \\
\text { users }\end{array}$ & $\begin{array}{l}\text { Only one tool for all } \\
\text { different heights as } \\
\text { needed }\end{array}$ \\
$\begin{array}{l}\text { 2. } 30 \text { inch for user } 121- \\
\text { 3. } 35 \text { inch for user } 152 \\
\mathrm{~cm}\end{array}$ & \\
$\begin{array}{c}\text { 4. } 40 \text { inch for users } \\
152-165 \mathrm{~cm}\end{array}$ & \\
\hline $\begin{array}{l}\text { Foam diameter } 63 \mathrm{~cm} \\
-101 \mathrm{~cm}\end{array}$ & $\begin{array}{l}\text { Foam diameter } 50 \\
\mathrm{~cm}\end{array}$ \\
\hline $\begin{array}{l}\text { Height of one tool } \\
\text { cannot be adjusted }\end{array}$ & $\begin{array}{l}\text { The height of the } \\
\text { tool can be adjusted } \\
\text { to a maximum of } 1 \\
\text { meter }\end{array}$ \\
\hline
\end{tabular}

Table 4. Differences between the

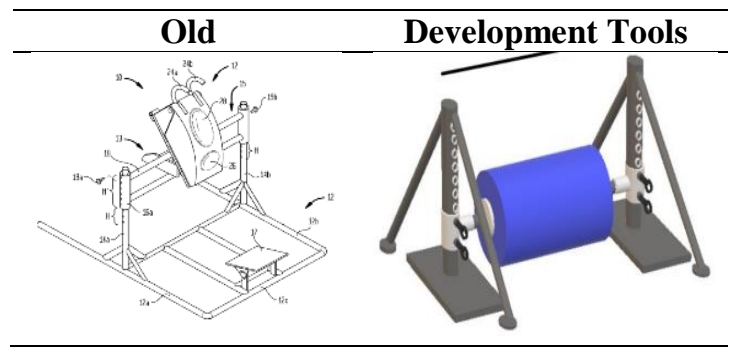

\section{Procedures}

a. Potentials and Problems Potential

$\mathrm{KBBI}$ is defined as an ability that has various possibilities or hopes for further development, either in the form of strength, power, or ability that is obtained by the community directly or through a long process.

b. Data Collection

From the results of needs analysis and interviews with athletes, coaches and coaches that have been carried out. The results can be concluded that the idea of development research is important for the development of a training tool flick flack so that it can help the trainer train to improve the flick flack.

c. Product Design

Furthermore, the researcher made the initial product in the form of a series of training tools development flick flack so that it could help coaches improve movements flick flack athletes'. In making products developed by researchers, researchers must consult the products with artistic gymnastics coaches and sports experts, in order to produce products that are useful and perfect for use.

d. Evaluation

After making the training tool flick flack the new finish, the researcher proceeded to the evaluation stage of the form of the exercise tool. Evaluation is carried out in order to improve the shape of the tool that has been made.

\section{Design or Data Analysis}

From the observations that the researcher made by observing, viewing, and interviewing, the researcher conducted a needs analysis of 18 artistic gymnastics athletes. Thus obtained $100 \%$ athlete requires tools practice flick flack exercises form flick flack. From the results of the needs analysis carried out, it can be concluded that athletes and training need training aids flick-flack for training flick-flack in the hope of improving the movement abilities of flick-flack novice athletes in artistic gymnastics. With this training tool, flick flack it can help coaches train the movement flick flack for novice athletes with the aim of making athletes excel in artistic gymnastics.

The first test is carried out after the initial design or model design of this tool has been observed, corrected and declared 
worthy of being tested by experts. In making the product developed by the researcher, the researcher validates the product with 3 expert trainers, 3 sports experts and 3 equipment / media experts to produce the perfect product. Can be seen in table 5 below.

Table 5. Recapitulation of expert validation assessments

\begin{tabular}{ccccc}
\hline Expert & $\begin{array}{c}\text { Total } \\
\text { Score }\end{array}$ & $\begin{array}{c}\text { Score } \\
\text { Max }\end{array}$ & $\%$ & Category \\
\hline Sport & 32 & 40 & $80 \%$ & $\begin{array}{c}\text { Good / } \\
\text { Used }\end{array}$ \\
\hline Trainer & 30.6 & 40 & $76.5 \%$ & $\begin{array}{c}\text { Good / } \\
\text { Used }\end{array}$ \\
\hline Media & 35.6 & 40 & $89 \%$ & $\begin{array}{c}\text { Good / } \\
\text { Used }\end{array}$ \\
\hline Total & 98.2 & 120 & $81,8 \%$ & $\begin{array}{c}\text { Good / } \\
\text { Used }\end{array}$ \\
\hline
\end{tabular}

In the recapitulation table 5 the average expert validation assessment shows that of the three sports experts the percentage is $80 \%$ with the good / used category, from the three coaches the percentage is $76.5 \%$ with the good / used category, and from the three media experts the percentage is $89 \%$ with good / used category. with an average percentage of each expert $81.8 \%$ in the good / used category. The average result of expert validation evaluation can be seen in Figure 1 below.

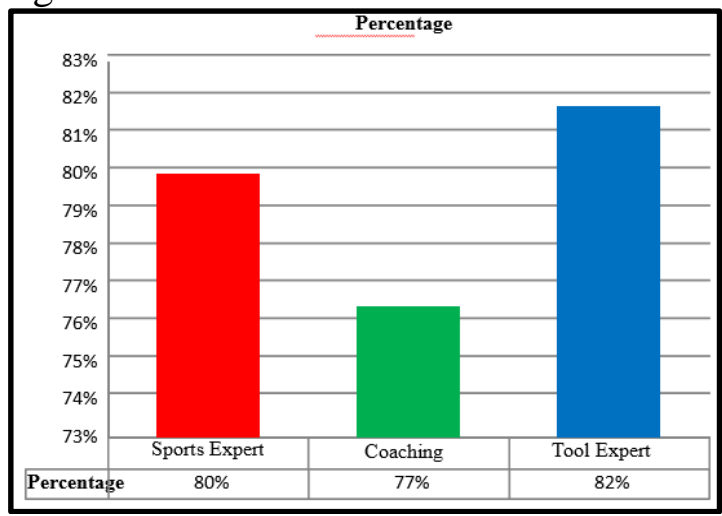

Figure 1. Comparison Graph of Expert Evaluation Results
From the comparison graph of the results of expert validation, the average percentage value obtained is $81.8 \%$, thus it can be stated that according to sports experts, coaches, and equipment / media experts get the category "Good / Used. ".

Next are some input from experts about the developed training tools, expert input for the tools can be seen in table 6 below.

Table 6. Inputs for improvement of tools developed

\begin{tabular}{|c|c|c|}
\hline No & Expert & Input / Suggestion \\
\hline 1 & Sports & $\begin{array}{l}\text { Tools that are made are very } \\
\text { useful for beginners with a } \\
\text { warm-up preceded. } \\
\text {. Tools that are made are good. } \\
\text {. This tool is in accordance } \\
\text { with the needs of novice } \\
\text { athletes. }\end{array}$ \\
\hline 2 & Trainers & $\begin{array}{l}\text { Great tool for beginners. } \\
\text {. Very useful tool for coaches } \\
\text { and athletes. } \\
\text { Tools are very helpful for } \\
\text { trainers. }\end{array}$ \\
\hline 3 & Media & $\begin{array}{l}\text { The construction of the } \\
\text { tool is sturdy for athletes to } \\
\text { use during training. } \\
\text { There should be a } \\
\text { determination of size when } \\
\text { raising and lowering the } \\
\text { foam according to the } \\
\text { athlete's height. } \\
\text { The whole tool is solid } \\
\text { because the supports used are } \\
\text { also heavy. }\end{array}$ \\
\hline
\end{tabular}

Small Group Trials

After the training tool was flick-flack validated and deemed feasible and met the criteria, the next step was to do small group trials. And for the small group test carried out at two different clubs, namely, Siahaan Gymnastic Club and Windy's Gymnastic Club with a total of 14 samples, the conclusion is that: 
1. $77 \%$ of athletes in the small group test said the training aid flick flack was attractive.

2. $70 \%$ of athletes in the small group test said training was flick-flack more attractive using the training aid flick flack.

3. $75 \%$ of athletes in the small group test said they were comfortable using the training aid flick flack.

4. $75 \%$ of athletes in the small group test said the training aid was flick flack easy to use.

5. $66 \%$ of athletes in the small group test said that the training flick-flack with the aid was easy to use.

6. $66 \%$ of athletes in the small group test said that practicing flick-flack using the device improved ability flickflack.

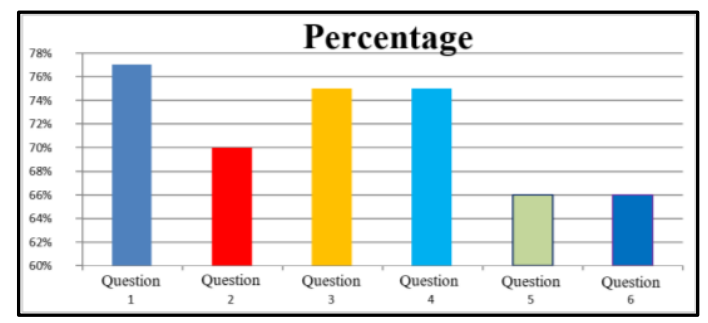

Figure 2. Graph of small group trial

Results From the results of small group trials of 14 athletes it was concluded that the training tool flick-flack met the criteria to be continued in large group trials because the percentage of questionnaire questions was between $66 \%-77 \%$. It can be concluded that this tool can be used using the drill method and the minimethod game can be continued after making some improvements to the tool.

After the small group trial was carried out, the large group trial was carried out. And for this large group test was carried out on athletes from 4 different clubs, namely, Siahaan Gymnastic Club, Windy's Gymnastic Club, Super Kids Gymnastic Club, QA. Gymnastic Club with 17 samples and the conclusions are:
1. $100 \%$ of athletes on the large group test said the training aid flick flack was attractive.

2. $98 \%$ of athletes in the large group test said that training was flick flack more attractive using the training aid flick flack.

3. $97 \%$ of athletes in the large group test said they were comfortable using the training aid flick flack.

4. $94 \%$ of athletes on the large group test said the training aid was flick flack easy to use.

5. $98 \%$ of athletes in the large group test said practice flick flack was easy with the device.

6. $94 \%$ of athletes in the large group test said that using the training aid flick flack can improve the ability flick flack.

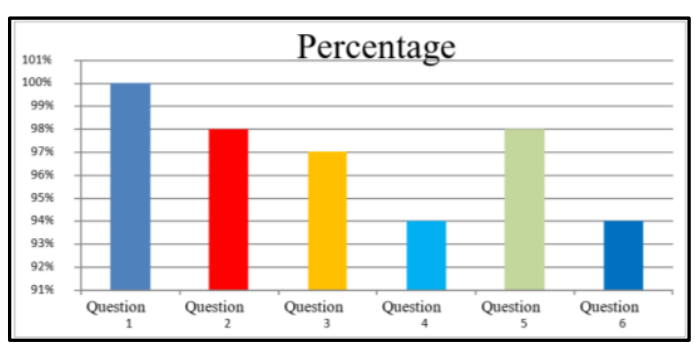

Figure 3. Graph of large group trial

Results From the results of large group trials on athletes after doing the training flick flack using the training aid flick flack, the athletes are given a questionnaire to fill in according to their own understanding. From the results of large group trials of 17 athletes, it was concluded that the training tool flick flack using the training aid flick flack met the criteria to be continued in the manufacture of mass products with the percentage for large group trials between $94 \%-100 \%$. It can be concluded that the training tool flick flack using the training tool flick flack can be used or suitable for training flick flack to improve the ability flick flack.

This is in line with the results of Tommy Soenyoto's research, concluding that the mushroom tool model product for men's artistic gymnastics can be used in 
improving the movement skills of junior and senior gymnastics athletes, is useful as a training tool, and a special athlete artistic gymnastics competition facility for beginners (Tommy, 2014). Furthermore, Arya Budhi Prasetya's research concluded that kayang media tools were well received by junior high school students, so that kayang tools were used as a tool for learning floor exercise for eighth grade students of SMP Negeri 1 Kragan (Prasetya, 2016).

\section{RESULT}

Development of this product aims to improve the ability of novice athletes when practicing the movement flick flack in artistic gymnastics. The quality of "Development ofTraining Tools for Flick Flack Beginner Athletes in Persani Medan in 2020" includes the criteria for "Use", the statement is concluded from the results of the analysis of the assessment of nine experts getting an average of $81.8 \%$, validation of 3 expert coaches is $76 \%$, validation 3 sports experts at $80 \%$, validation 3 tool / media experts, in the small group trial 14 athletes with 6 questions got $66 \%-77 \%$ and the large group trial 17 athletes with 6 questions $94 \%-100 \%$.

This tool is very helpful for trainers in practicing the movement flick flack for beginners. Based on the discussion of developing the training tool, flick flack it has advantages, including:

1. Athletes are more enthusiastic in training with the training aid flick flack.

2. Athletes get new experience in training when training using the tool flick flack.

3. Can assist trainers in practicing flick flack with the training aid flick flack.

Based on these advantages, this tool also has several disadvantages such as having to raise and lower the foam several times to adjust to the athlete's height.

\section{CONCLUSION}

Research on stick development concluded that stick gymnastics is appropriate and can be implemented as a physical learning medium in elementary schools with minimal facilities, in small and large scale trials, stick gymnastics can effectively improve students' psychomotor, affective and cognitive abilities, and seen from the participation of the stick gymnastics model can accepted by students and physical education teachers (Mubin, 2019). Furthermore, Albadi et al's research in developing tools concluded: using remote control and headsets, athletes focus more on personal abilities without thinking about collaboration, acceleration and communication. And the use of more tools makes athletes more confident and more independent in sprinting training. Likewise, coaches are more focused and conveyed in delivering information and more efficiently training blind athletes in sprint running numbers by looking at personal abilities and motivations (Sinulingga et al., 2021).

Based on the results of the field trials and the results of the researchers' discussion, it can be concluded that:

1. Athletes in the small group test said the training aid flick flack was attractive.

2. Athletes in the small group test said that training was flick-flack more attractive using the training aid flick flack.

3. Athletes in the small group test said that it was comfortable to use the training aid flick flack.

a. Thistraining tool product flick flack can be used according to the height and size of the athlete in its use.

b. This training tool product is suitable for practicing the technique flick flack. 
c. This product uses the training aid flick flack so that the athlete's ability can increase faster.

d. This Training aid flick flack has a fairly heavy sturdiness, which is around $50 \mathrm{~kg}$.

e. The Training tool flick flack as a whole is very safe for athletes to use.

4. Athletes in the small group test said the training aid was flick-flack easy to use.

5. Athletes in the small group test said that training flick-flack using the tool was made easy to use.

6. Athletes in the small group test said that practicing flick-flack using this tool can improve ability flick-flack.

Based on the results of field trials and the results of the researchers' discussion, it can be suggested that:

a. Thistraining tool product flick flack can be used according to the height and size of the athlete in its use.

b. This training tool product is suitable for practicing the technique flick flack.

c. This product uses the training aid flick flack so that the athlete's ability can increase faster.

d. This Training aid flick flack has a fairly heavy sturdiness, which is about $50 \mathrm{~kg}$.

e. The Training tool flick flack as a whole is very safe for athletes to use.

Eni Yusnita Pardede's research concluded, based on the collection of data from field trials and discussion of research on the snake and ladder game model product, the interest of elementary school students was increasing effectively and efficiently. It also increases the interest in learning of elementary school students in motivating and actively participating in the learning process (Pardede, 2020). So it can be concluded that research on the development of the tool is useful and needed in improving skills for athletes and coaches as well as gymnastics organizations, especially for beginner gymnastics athletes, PERSANI Medan, who are all artistic athletes in Medan. In line with the research results, it was revealed that developing Acrosport content using technology in the teaching and learning process and practicing was very profitable (Ávalos et al., 2020).

\section{REFERENCES}

Ávalos, M. A., Garde, A., \& Vega, L. (2020). Technologies and selfassessment as strategies for collaborative gymnastic learning. Science of Gymnastics Journal, 12(3), 313-324.

Exupério, I. N., Agostinete, R. R., Werneck, A. O., Maillane-Vanegas, S., Luiz-de-Marco, R., Mesquita, E. D. L., Kemper, H. C. G., \& Fernandes, R. A. (2019). Impact of artistic gymnastics on bone formation marker, density and geometry in female adolescents: ABCD-growth study. Journal of Bone Metabolism, 26(2), $75-82$. https://doi.org/10.11005/jbm.2019.26 .2 .75

Firmansyah, H. (2017). Hubungan Antara aspek Fisik dan Psikologis Studi pada Atlet Senam Artistik Putra Jawa Barat. Humanitas, 14(1), 78-89.

Hadjarati, H., \& Haryanto, A. I. (2020). Motivasi untuk hasil pembelajaran senam lantai. Multilateral: Jurnal Pendidikan Jasmani dan Olahraga, 19(2), 137-145.

Mubin, F. (2019). Stick Gymnastic Development for Learning Material Rhythmic Activities at Physical Education in Elementary Schools Article Info. Journal of Physical Education and Sports, 8(1), 69-75.

Nurkadri. (2018). Goenrich Basic Technique Model with Playing Approach for a Beginner Tennis Player. Faculty of Sport Science 
Universitas Negeri Medan, 96-100.

Palmizal, A., Pujianto, D., Nurkadri, \&

Laksana, A. A. N. P. (2020).

Development of a creative gymnastics model to improve basic locomotor movements for students in elementary school. International Journal of Human Movement and Sports Sciences.

https://doi.org/10.13189/saj.2020.080 714

Pardede, E. Y. (2020). Development of the Snake Game Model for Basic Movement Skills in SD Medan Struggle Students. 23(UnICoSS 2019), 148-149. https://doi.org/10.2991/ahsr.k.200305 .042

Paul Ford, Mark De Ste Croix , Rhodri Lloyd , Rob Meyers, M. M., \& Jon Oliver, K. T. \& C. W. (2011). The Long-Term Athlete Development model: Physiological evidence and application. Journal of Sports Sciences, 29(4), 389-402. https://doi.org/10.1080/02640414.20 10.536849

Prasetya, A. B. (2016). Pengembangan Media Alat Bantu Kayang Pembelajaran Senam Lantai. Journal of Physical Education, Sport, Health and Recreation, 5(3), 114-116.

Ratih Langenati, M. J. (2015). Pengaruh Self-Hypnosis Terhadap Konsentrasi Pada Atlet Senam Artistik. character Unesa, 3(2), 1-6.

Sinulingga, A., Novita, N., \& Nababan, J. T. M. (2021). Implementation Of Training Aid Tools Development (Remote Control and Headset) For Sprint Tunanetra Athletes. Kinestetik : Jurnal Ilmiah Pendidikan Jasmani, 5(1), 17-25. https://doi.org/10.33369/jk.v5i1.1334 1

Soni Kurniawan, Tono Suhihartono, yarmani, D. (2018). Kontribusi kelentukan pinggang dan. Kinestetik :
Jurnal Ilmiah Pendidikan Jasmani, 2(2), 247-257.

Sugiono. (2016). Metode Penelitan Kuantitatif, kualitatif dan R\&D. Bandung: Alfabeta.

Sugiyono. (2012). Metode Penelitian Kuantitatif, Kualitatif dan R\&D. Alfabeta.

Sujito, S. (2020). Pengembangan Model Pembelajaran Passing Bawah Bolavoli. Jurnal Penjakora. JURNAL PENJAKORA, 7(1), 30-39.

Tommy, S. (2014). Pengembangan Prototipe Alat Jamur Cabang Olahraga Senam Artistik Putra Di Provinsi Jawa Tengah. Journal of Physical Education Health and Sport, 1(1), $\quad 1-8$. https://doi.org/10.15294/jpehs.v1i1.3 005

Yuniarni, D., Sari, R. P., \& Atiq, A. (2019). Pengembangan Multimedia Interaktif Video Senam Animasi Berbasis Budaya Khas Kalimantan Barat. Jurnal Obsesi : Jurnal Pendidikan Anak Usia Dini, 4(1), 290. https://doi.org/10.31004/obsesi.v4i1. 331 